\title{
The Effectiveness of Multimedia Instructional Learning Packages in Enhancing Secondary School Students' Attitudes toward Biology
}

\author{
Bukola Omowumi Akinbadewa \\ Obafemi Awolowo University, Ile-Ife, Osun State, Nigeria, bukolaakinbadewa@yahoo.com \\ Olaniyi Alaba Sofowora \\ Obafemi Awolowo University, Ile-Ife, Osun State, Nigeria
}

\begin{abstract}
The study investigated the effectiveness of multimedia learning packages in improving the attitudes of students toward learning Biology in secondary schools. The study employed a quantitative and qualitative research approach. The population for the study consisted of all students offering Biology as a subject in the senior secondary schools in Ibadan North Local Government Area of Nigeria, from where a sample of 80 students was randomly selected from three secondary schools and assigned to three groups (one control and two experimental groups). Two multimedia instructional learning packages (MILP) were designed for the study. The topic treated was Cell Division, and the study lasted for six weeks. The packages and all instruments used were validated for content and construct validity, and reliability test was also done. The results showed that multimedia instructional packages used in teaching and learning Biology in secondary schools enhanced better students' engagements and positive attitudes toward learning. It was concluded that students developed positive attitudes toward learning Biology after using the packages and that multimedia instructional packages are an interesting and creative method of teaching, learning, and enhancing positive attitudes towards learning among secondary school students.
\end{abstract}

Keywords: Multimedia instructional learning packages, Attitude, Meaningful learning, Academic achievement, Biology, Secondary schools

\section{Introduction}

Students' attitudes, whether positive or negative, are found to directly or indirectly affect their learning. Positive students' attitudes result in successful learning, and, negative students' attitudes have been linked to the poor performance of students. Literature showed that there is a noticeable gap in students' attitudes or perceptions of learning. Low information literacy level and negative attitude to learning has been found to constitute a serious obstacle to the enhancement of student's learning and are indicators of the necessity for integrating emerging technologies in learning, especially, in the field of Science (Davies \& West, 2014; Bawden, 1990). To this effect, technology integration in education is suggested and explored. Several studies have been conducted to examine the impact of integrating multiple media modalities into the curriculum, more particularly in the areas where students have difficulties in their ability to envision and manipulate multidimensional information spaces (Jekinson, 2009).

Hence, to aid understanding of complex concepts such as is found in Science, Mathematics, Medicine, and Engineering, amongst others, researchers such as Mayer (2005) suggested visual and auditory representation of information. Similarly, Sweller (1989) suggested the cognitive load theory, noting that information should be presented in schemas (small chunks) so that the working memory is not overloaded. While several studies have reported that multimedia can improve academic achievement (Park, et al., 2019; Moussa-Inaty, et al., 2019; Saputri \& Indriayu, 2018), some other studies shared contrary opinion about the effectiveness of multimedia in improving the attitude of students towards Science and its related disciplines (Smith, Cavanaugh, \& Moore, 2011; Ercan, 2014; Zahorec, Haskova \& Bilek, 2014; Lipnevich, Gjicali, \& Krumm, 2016; and Kareem, 2018).

Biology is one of the Science subjects that occupy a unique position in schools curriculum. It is an integral part of Science and its importance in the field of science cannot be overemphasized. However, the performance of students in the subject has been appalling. In attempt solve the problem, researchers (such as Ahmed \& Abimbola, 2011; Cimer, 2012; Agboghoroma \& Oyovwi, 2015; Etobro \& Fabinu, 2017) found that many students perceive Biology topics as boring, abstract and too difficult to understand. Also, there is the problem of 
overcrowded classrooms, and poor teaching methods adopted by teachers (Olaleye, Ajayi, \& Oyebola, 2017; Gimba, Hassan, Yaki, \& Chado, 2018).

Positive attitude toward school and learning has been identified as a precursor to effective learning and academic success (Loyd \& Gressard, 1984a; Topală, 2014; Verešová \& Mala, 2016 and Dagnew, 2017). Indeed, research has demonstrated that positive attitudes increase the potential for academic success. Conversely, a negative attitude makes academic success less likely (Loyd \& Gressard, 1984b). Also, a new brain scan study carried out in Stanford revealed that a positive attitude makes the brain work better (Stillman, 2018). Hence, there is a need to determine if multimedia can indeed positively influence the attitudes of students towards learning Biology in secondary schools. Fisbien and Ajzen (1975) explained attitude as an important concept that is often used to understand and predict people's reaction to an object or change, and how behaviour can be influenced. Taking into account how the use of technology to support learning in secondary education is becoming more and more relevant, Gros, Garcia and Escofet (2012) opined that the debate must focus on real evidence about students' attitudes toward ICT use for learning purposes. This study seeks to provide such evidence.

\section{Statement of the Problem}

Students' poor performance in Science has given a lot of concerns to parents, science teachers and government. The poor performance of the students has been attributed to a negative attitude to learning, inadequate facilities, overcrowded classrooms, lack of suitable and adequate science equipment, and poor background of students at the foundation level. Other factors include students' phobia for science subjects and the erroneous belief that Biology is a difficult subject. Teachers are not left out as they sometimes evade teaching some aspects of the subject because of its abstractness. The state of most laboratory in schools has made the use of modern methods and experiments difficult, and the present economic recession and irregular payment of teachers' salaries are contributing factors to the already complicated situation. However, there is a ray of hope as the use of multimedia learning seems to remedy the situation.

However, the problem here is that there are conflicting opinions about the effectiveness of these media in teaching and learning. The old school of thoughts holds the assumption that multi-media learning distracts learners from learning. Hence, we have two schools of thought which includes those who share the opinion that Multi-media learning is effective in enhancing learning and the others that opined that it should not be integrated into instruction. Other challenges faced are that, even in schools where there are facilities for multimedia learning, most of the students do not utilize them for learning because of lack of constant supply of electricity and high cost of maintenance.

Also, in many schools where the facilities are available, they are closely guarded and not within the reach of the students to use thereby discouraging the students from utilizing them for individualized learning. These problems have made students rely on the teacher's instructions only, and year in year out, students' performance, particularly in Sciences and its related disciplined have been appalling, and this has also contributed to poor students' attitude and perception of Science, particularly Biology, making many students perceive biology as a boring, abstract and too difficult subject to understand. Therefore, there is a need to explore a change in teaching strategy from the conventional long-standing "talk and chalk" method, to computer-based multimedia supported one and see its effect on students' attitude and engagement in Biology.

\section{Research Objectives}

The objectives of this study are as follows:

i. examine the effectiveness of multimedia learning in enhancing students' engagements and attitude towards Biology in secondary schools;

ii. investigate the effectiveness of the multimedia packages in enhancing students' academic achievement in Biology

\section{Research Questions}

i. What is the level of achievement of the students after being exposed to the treatments? 
ii. What is the attitude of students towards the multimedia instructional learning packages?

iii. How effective are the packages in enhancing students' engagement and attitude towards Biology in the selected area of study?

\section{Theoretical Framework}

This study was guided by the Cognitive Theory of Multi-media learning of Mayer (2005) and Meaningful Learning by Smith and Ragan (1999). The Cognitive Theory of Multimedia Learning describes how learners build mental representations of multi-media materials. The theory explains that students learn more deeply with a combination of words and pictures than with either words or pictures alone. Based on the theory, multimedia brings about meaningful learning, and meaningful learning can only be said to have been achieved if the learner can apply the knowledge of what he/she has learned in new situations. The Cognitive theory of multimedia learning presents an idea that care must be taken when designing multimedia instructions so that the multimedia elements are selected dynamically and organized to produce logical mental constructs.

According to Smith and Ragan (1999), there is a cognitive process that precedes meaningful learning. For it to occur, the learner must be actively involved in knowledge constructs. The process must also involve: Selection of relevant information; Organization of information in a meaningful way, and Integration of information with learner prior knowledge (see Figure 1). The principles extracted from these theories are utilized in the design of the multimedia instructional learning packages

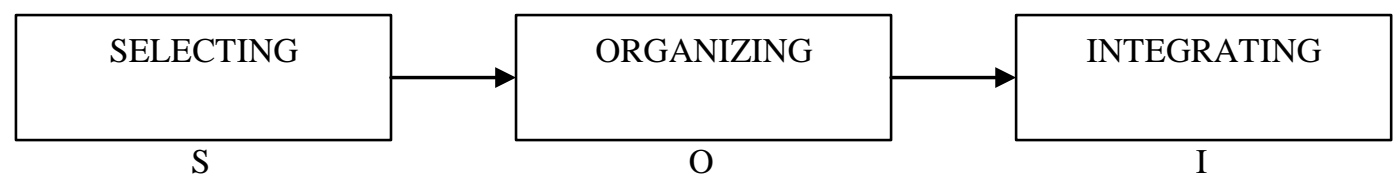

Figure 1. SOI Meaningful Learning Model

The Technology Acceptance Model (TAM) is aimed at developing a model for explaining and predicting users' acceptance of a certain information system (Davis, Baagozzi \& Warshaw, 1989). The theory explains that human behaviour is directly preceded by the intention to perform the behaviour and that three factors are found to influence intentions: personal beliefs, one's norms, and the (perceived) amount of behavioural control an individual has. From the perspective of TAM, perceived ease of use and perceived usefulness are assumed to be related to the acceptance of a technology system. TAM assumed that external variables affect perceived usefulness and perceived ease of use directly, both of which were factors in the Technology Acceptance (Davis et al., 1989; Legris, Ingham \& Collerette, 2003).

Applying the above to this study, perceived usefulness and perceived ease of use is the belief that the users perceive that the multimedia instructional learning packages would enhance their learning performance and be easy to use. Hence, a strengthening of this belief creates a positive attitude toward multimedia instructions. The attitude toward using a given technology could be hinged on the overall evaluation that predicted a user's likelihood of adopting the technology. Past researches indicated that attitude was influenced by both perceived ease of use and perceived usefulness (Dabholkar \& Bagozzi, 2002; Hussein, 2017; Weng, Yang, Ho, \& Su, 2018; Teo, Zhou, Fan, \& Huang, 2019). Hence, if students believe that multimedia packages would help them to have a better understanding of a topic and better performance, they might accept its use and therefore, a commitment of students to its use may also be studied.

\section{Methodology}

The study adopted a quantitative and qualitative research approach. For the quantitative research, the study employed a posttest-only experimental research design, and for the qualitative aspect, a focus group discussion was done at the end of the study to further contextualize the findings, get beyond superficial answers, and uncover insights into the respondents' attitudes. 


\section{Study Group}

The population consisted of all students offering Biology as a subject in the senior secondary schools in Ibadan North Local Government Area, Nigeria, from where a sample of 80 students was randomly selected from three government secondary schools. The samples were randomly assigned to two experimental groups and one control group. The first experimental group was exposed to MILP 1, and the second experimental group was exposed to MILP 2. The third group was the control group that used the conventional "chalk and talk" instructional method. The topic treated was cell division: mitosis and meiosis. The study lasted for six weeks.

\section{Research Instruments}

The following instruments were used for the study: Multimedia instructional learning package 1 (MILP 1); Multimedia instructional learning package 2 (MILP 2); Multimedia instructional package workbook (MIPWB); Multimedia Learning Attitudinal Scale (MLAS); and Focus group discussion guide (FGDG).

\section{Multimedia Instructional Learning Package 1 (MILP 1)}

The package was designed by the researchers based on the cognitive principle of multimedia learning as explained by Mayer (2005). The package was designed to teach one of the experimental groups. It includes contents on cell division. The following multimedia elements were used in the design: texts, sounds, narration, navigational structure, images.

\section{Multimedia Instructional Learning Package 2 (MILP 2)}

This instructional package contained contents on the topic: cell division. The following multimedia elements were used in the design: texts, short videos, navigational structure/ hyperlinks, Sounds, narrations, and images. After the packages were designed, they were given to three experts in Educational Technology, Tests and Measurement, and one Biology teacher for face and content validity after which they were used on a representative sample. Corrections were made before they were used in the main study.

\section{The Multimedia Instructional Package Work Book (MIPWB)}

The workbook was designed by the researcher for students in the experimental groups to answer the theory questions that were provided when interacting with the packages. The workbook was in two parts. Part A included the students' demographic data, and part B was the area for answering questions.

\section{Multimedia Learning Attitudinal Scale (MLAS)}

MLAS measured the effectiveness of the packages in enhancing students' attitude towards Biology in the study area (see Appendix 1). It comprised two sections. The first section, section A comprised of students' demographic data. The second part, section B contained 10 items using a 5-point Likert scale: Strongly Agree (SA), Agree (A), Uncertain (U), Disagree (D), and Strongly Disagree (SD). The face and content validity of the instrument was determined before it was used in the study. The instrument was also administered on 20 students exposed to the packages that were not part of the samples, to determine its reliability and a Cronbach alpha value of 0.90 was obtained.

\section{Biology Achievement Test}

The Biology Achievement Test (BAT) consists of 30 multiple-choice questions on Cell Division with four possible answers for each question (see Appendix 2). The items were extracted from past questions between the years 2005 and 2015 from West Africa Examination Council (WAEC), a standardized examination body in West Africa. To ensure further validity of the instrument for the set of students in the study, the face and content validity of the instrument was done. Two Biology teachers, two Educational Technologists and one expert of Test and Measurement participated in the validation of the instrument. The BAT was also trial tested on 20 students from two schools not participating in the research to test for its reliability. From the students' 
responses, a reliability coefficient of 0.72 was established using the Kuder-Richardson (KR 20) formula. The instrument was used as the post-test in the three groups.

\section{Focus Group Discussion Guide}

This instrument was designed and used by the researcher for the qualitative aspect of the study (see Appendix 3). The guide consists of 7 items, and measures three constructs: perceived usefulness, perceived ease of use and perceived enjoyment. The questions in the guide were asked the students at the end of the study.

\section{Data Analysis}

Data collected were analyzed using descriptive statistics of mean, standard deviation, frequencies, and percentages.

\section{Results}

\section{Demographics}

Table 1 showed that 80 students participated in the study, out of which $55 \%$ were male and $45 \%$ female. Furthermore, $80 \%$ of the students were between 14 and 16 years. Similarly, $10 \%$ of the students were between the ages of 11 and 13 , and $5 \%$ of the students were 17 years and above.

Table 1. Gender and Age Distribution of the Students

\begin{tabular}{|c|c|c|}
\hline Variables & Frequencies & Percentage (\%) \\
\hline \multicolumn{3}{|l|}{ Gender } \\
\hline Male & 44 & 55.0 \\
\hline Female & 36 & 45.0 \\
\hline \multicolumn{3}{|l|}{ Age } \\
\hline $11-13$ & 8 & 10.0 \\
\hline $14-16$ & 64 & 80.0 \\
\hline 17 and above & 4 & 5.0 \\
\hline No indication & 4 & 5.0 \\
\hline Total & 80 & 100 \\
\hline
\end{tabular}

\section{Answers to the Research Questions}

\section{R.Q 1: What is the level of students' achievement in Biology when exposed to the treatments?}

Table 2 showed the performance of students according to their treatment groups. In the control group, $50 \%$ of the students in the group failed the test, $50 \%$ had a credit score, and none of the students in the group had a distinction. However, in the experimental group I, 9.5\% of the students failed the test, $80.9 \%$ of the students had credit score, and $9.5 \%$ had distinction. In the experimental group II, none of the students failed the test, $52.6 \%$ of the students had credit pass and $47.4 \%$ had distinction. This implies that students in the control group had a low level of academic achievement in Biology compared to the other groups. Those in the experimental group I had a high level of academic achievement and those in experimental group II had the highest level of academic achievement amongst the three groups.

Table 2. Students' Performance based on Treatment Groups

\begin{tabular}{llll}
\hline Score & Control group & Exp. group I & Exp. group II \\
\hline $0-12$ & $20(50.0)$ & $02(9.5)$ & $0(0.0)$ \\
$13-15$ & $07(17.5)$ & $05(23.8)$ & $0(0.0)$ \\
$16-18$ & $09(22.5)$ & $07(33.3)$ & $03(15.8)$ \\
$19-21$ & $04(10.0)$ & $05(23.8)$ & $07(36.8)$ \\
22 and above & $0(0.0)$ & $02(9.5)$ & $09(47.4)$ \\
\hline Total & 40 & 21 & 19 \\
\hline
\end{tabular}




\section{R.Q 2: What is the attitude of students towards the multimedia instructional packages?}

Table 3 revealed that $80.3 \%$ of the students in the two experimental groups exhibited a positive attitude towards the multimedia instructional packages and rated the packages as very effective in developing positive attitudes towards Biology (cumulative men = 3.21). Majority of the students agreed that they were very confident about answering the biology questions after using the multimedia instructional packages (mean $=3.43$ ). They also rated the multimedia instructional packages high as tools for enhancing individualized learning $($ mean $=3.48)$. Similarly, the students rated multimedia instructional packages as a creative method of teaching $($ mean $=3.65)$. Besides, the multimedia packages were rated as very interesting (mean $=3.13$ ) and the students believed that the packages would enhance better performance in Biology $($ mean $=2.98)$.

Table 3. Students' Attitude towards the Multimedia Instructional Packages

\begin{tabular}{|c|c|c|c|c|c|c|c|c|}
\hline $\mathrm{s} / \mathrm{n}$ & Items & SA & A & $\mathrm{U}$ & $\mathrm{D}$ & SD & Mean & SD \\
\hline 1. & $\begin{array}{l}\text { I feel very confident } \\
\text { towards answering } \\
\text { Biology questions after } \\
\text { using the multimedia } \\
\text { instructional package }\end{array}$ & $\begin{array}{l}18 \\
(45.0)\end{array}$ & $\begin{array}{l}21 \\
52.5)\end{array}$ & $\begin{array}{l}- \\
(0.0)\end{array}$ & $\begin{array}{l}1 \\
(2.5)\end{array}$ & $\begin{array}{l}- \\
(0.0)\end{array}$ & 3.43 & .55 \\
\hline 2 & $\begin{array}{l}\text { The multimedia package } \\
\text { allowed me to learn on } \\
\text { my own }\end{array}$ & $\begin{array}{l}19 \\
(47.5)\end{array}$ & $\begin{array}{l}21 \\
(52.5)\end{array}$ & $\begin{array}{l}- \\
(0.0)\end{array}$ & $\begin{array}{l}- \\
(0.0)\end{array}$ & $\begin{array}{l}- \\
(0.0)\end{array}$ & 3.48 & .51 \\
\hline 3 & $\begin{array}{l}\text { The use of multimedia } \\
\text { instructional package for } \\
\text { learning Biology was a } \\
\text { good idea }\end{array}$ & $\begin{array}{l}26 \\
(65.0)\end{array}$ & $\begin{array}{l}14 \\
(35.0)\end{array}$ & $\begin{array}{l}- \\
(0.0)\end{array}$ & $\begin{array}{l}- \\
(0.0)\end{array}$ & $\begin{array}{l}- \\
(0.0)\end{array}$ & 3.65 & .48 \\
\hline 4 & $\begin{array}{l}\text { I found the multimedia } \\
\text { package very interesting } \\
\text { for learning Biology }\end{array}$ & $\begin{array}{l}22 \\
(55.0)\end{array}$ & $\begin{array}{l}17 \\
(42.5)\end{array}$ & $\begin{array}{l}- \\
(0.0)\end{array}$ & $\begin{array}{l}1 \\
(2.5)\end{array}$ & $\begin{array}{l}- \\
(0.0)\end{array}$ & 3.53 & .55 \\
\hline 5 & $\begin{array}{l}\text { I enjoyed the evaluation } \\
\text { questions in the packages }\end{array}$ & $\begin{array}{l}24 \\
(60.0)\end{array}$ & $\begin{array}{l}10 \\
(25.0)\end{array}$ & $\begin{array}{l}6 \\
(15.0)\end{array}$ & $\begin{array}{l}- \\
(0.0)\end{array}$ & $\begin{array}{l}- \\
(0.0)\end{array}$ & 3.15 & 1.41 \\
\hline 6 & $\begin{array}{l}\text { I know I would perform } \\
\text { better in Biology if my } \\
\text { teacher frequently uses } \\
\text { multimedia packages like } \\
\text { this to teach other topics } \\
\text { too }\end{array}$ & $\begin{array}{l}19 \\
(47.5)\end{array}$ & $\begin{array}{l}11 \\
(27.5)\end{array}$ & $\begin{array}{l}4 \\
(10.0)\end{array}$ & $\begin{array}{l}4 \\
(10.0)\end{array}$ & $\begin{array}{l}2 \\
(5.0)\end{array}$ & 2.98 & 1.31 \\
\hline 7 & $\begin{array}{l}\text { I like the navigational } \\
\text { structure of the package }\end{array}$ & $\begin{array}{l}15 \\
(37.5)\end{array}$ & $\begin{array}{l}20 \\
(50.0)\end{array}$ & $\begin{array}{l}4 \\
(10.0) \\
\end{array}$ & $\begin{array}{l}1 \\
(2.5)\end{array}$ & $\begin{array}{l}- \\
(0.0)\end{array}$ & 3.05 & 1.15 \\
\hline 8 & $\begin{array}{l}\text { Interacting with this } \\
\text { package made Biology } \\
\text { interesting to learn }\end{array}$ & $\begin{array}{l}17 \\
(42.5)\end{array}$ & $\begin{array}{l}19 \\
(47.5)\end{array}$ & $\begin{array}{l}4 \\
(10.0)\end{array}$ & $\begin{array}{l}- \\
(0.0)\end{array}$ & $\begin{array}{l}- \\
(0.0)\end{array}$ & 3.13 & 1.16 \\
\hline 9 & $\begin{array}{l}\text { The package did not } \\
\text { satisfy my need for } \\
\text { instruction }\end{array}$ & $\begin{array}{l}3 \\
(7.5)\end{array}$ & $\begin{array}{l}8 \\
(20.0)\end{array}$ & $\begin{array}{l}6 \\
(15.0)\end{array}$ & $\begin{array}{l}9 \\
(22.5)\end{array}$ & $\begin{array}{l}14 \\
(35.0)\end{array}$ & 2.55 & 1.43 \\
\hline 10 & $\begin{array}{l}\text { The time I spent using the } \\
\text { package was a waste }\end{array}$ & $\begin{array}{l}1 \\
(2.5)\end{array}$ & $\begin{array}{l}4 \\
(10.0)\end{array}$ & $\begin{array}{l}4 \\
(10.0)\end{array}$ & $\begin{array}{l}6 \\
(15.0)\end{array}$ & $\begin{array}{l}25 \\
(62.5)\end{array}$ & 3.18 & 1.32 \\
\hline
\end{tabular}

R.Q 3: How effective is the package in enhancing students' engagement and attitude towards learning of Biology in the selected area of study?

Qualitative Analysis of Focus Group Discussion: Focus group discussion was used to measure students' interaction, engagement and attitude towards the treatment in the experimental groups. Three constructs were used to gather the report: Perceived Usefulness (PU), Perceived Ease of Use (PEU) and Perceived Enjoyment (PE). Two focus group discussion was done, one in the experimental group I, consisting of 21 students, and the other in experimental group II, consisting of 19 students. Responses from the two groups are quite similar. Hence, they are summarized together. Table 4 provides a summary of responses from the focus group discussion in the experimental groups. 
Table 4. Summary of Responses Elicited from Focus Group Discussion in the Experimental Groups

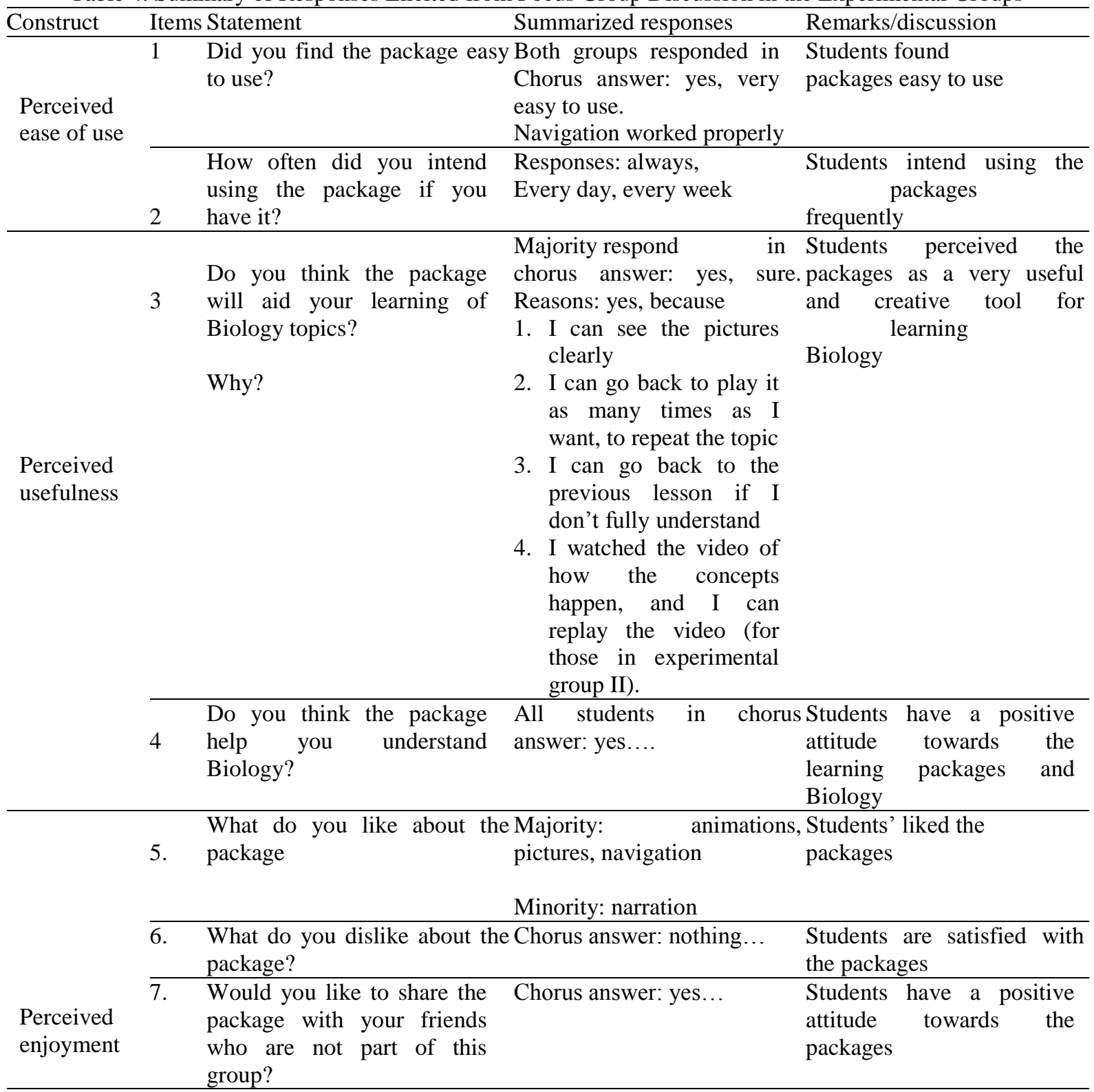

\section{Discussion}

The findings of the study showed that multimedia instructional learning packages enhanced students' academic achievement in biology. Students in the experimental groups exposed to the multimedia instructional learning packages had higher achievement scores than those in the control group that was exposed to the conventional teaching method. The reason for the higher achievement of the experimental groups might be because their instruction was active, interesting and personalized, with a student to a computer. Therefore, extraneous factors such as noise and other distractions were controlled.

An additional explanation for this effect could be associated with the interesting activities students were engaged in while interacting with the packages. These activities include voice narrations, navigational structures, animations, evaluation questions, immediate feedback, and short videos (for those in experimental group II). This finding is in agreement with the assertion of Mayer (2009) that using multimedia was more effective when it is interactive and under the control of the learner. Also, this finding supports previous studies that multimedia learning packages enhanced students' academic achievement (Saputri \& Indriayu, 2018; Saputri \& Indriayu, 2018; Park, et al., 2019; Sahronih, Purwanto, \& Sumantri, 2019; Yeşilbağ, Korkmaz, \& Çakir, 2020; Ayittey, Arthur-Nyarko, \& Onuman, 2020). The higher achievement score of students exposed to the MILP 2 could be as a result of the short video clips integrated into the package for each topic, which was 
not found in MILP I. This was in line with the finding of Carmichael, Reid, \& Karpicke (2018) that videos could help focus users' attention and provide clarity and explicitness to concepts beyond what was made possible with pictures or words alone. Therefore, integrating videos clips into multimedia packages could positively impact learning than graphics without video.

The findings of the study also revealed that students exhibited positive attitudes towards multimedia instructional learning packages and were of the view that learning Biology became interesting, creative and activity-based. Students also exhibited a higher confidence level in answering questions in Biology after utilizing the packages. This implies that the use of multimedia packages enhanced better students' perception of Biology, improved their attitude towards the subject and subsequently results in a higher learning outcome. Corroborating the present findings were previous studies (such as of Ercan, 2014; Zahorec, et al., 2014; Shah \& Khan 2015; Ilhan \& Oruç, 2016; Solpuk, 2017; Kareem, 2018; Park, et al., 2018) that revealed that attitude affects student achievement, and that multimedia assisted teaching was effective in improving students' academic achievement in different subjects.

Similarly, the analysis of the focus group discussion revealed that students have a positive perception of multimedia instructional learning packages in terms of its usefulness in learning, ease of use and enjoyment. Utilizing such packages made the learning of Biology very interesting. This finding is similar to that of Vilia, et al. (2017) that revealed that attitude has a significantly positive relationship with students' achievement. This has implications for teaching and learning in schools. It is an indication that both attitudinal and cognitive variables should be considered when designing instruction and learning contents in Biology. Hence, instructions should be designed to be interesting, and not vague or overloading to the students. To achieve this, instructions should be broken into small engaging units that students can focus attention at a time, making them active participants in the learning process, and positively influencing their attitudes toward learning.

The results of this study revealed that students find multimedia packages interesting, positively engaging, and impactful for learning. This finding is in agreement with that of Vagg, Bolger, Balta, \& Lone (2020) that students like when multimedia are integrated in their school's curriculum. Likewise, this finding is in agreement with that of Vilia, et al. (2017) carried out among some $9^{\text {th }}$ grade Portuguese students that both attitude and cognitive variables have impacts on the academic achievement of students in science education, and both should be considered when designing educational interventions.

Similarly, the result of the experimental study conducted by Chakraborty (2019) among some randomly selected secondary school class VIII Students in West Bengal reveals that multimedia instructional packages enhanced the participation rate of students and engage them in learning. The following scholars also found that multimedia use enhanced students' motivation, achievement and positively affected their attitudes towards learning (Janssen \& O’Brien 2014; Beydogan \& Hayram, 2015; Ilhan \& Oruç, 2016; Verešová, 2016; Omwirhiren \& Anderson, 2016 and Weng, Ho, Yang, \& Weng, 2018). Therefore, the result of this study revealed that attitude toward learning is an important precursor to academic achievement, and the better the attitude, the higher the academic output.

\section{Conclusions}

The results of the study showed that multimedia instructional learning packages were an interesting and creative method of teaching and learning Biology and that the multimedia packages enhanced meaningful learning and improved students' attitudes towards Biology. Therefore, it is concluded that multimedia instructional packages be utilized in secondary schools for improved academic achievement, engagement and to improve students attitudes toward learning Biology.

Based on the analysis of the data, the following are the summary of the findings:

i. It was found that multimedia learning packages were an interesting and creative method of teaching and learning Biology.

ii. It was also found that students developed a positive attitude towards learning of Biology after being exposed to the packages.

iii. Similarly, the packages enhanced better students' engagement during learning.

iv. Students have a positive attitude towards multimedia instructional learning packages. 


\section{Recommendations}

Based on the result of this study, the following recommendations are made:

i. Multimedia instructional packages should be introduced to secondary schools for teaching and learning different subjects, most especially Biology.

ii. Multimedia instructional packages should be utilized in secondary schools to develop a better attitude towards biology and other science subjects among secondary school students.

iii. Pre-service teachers in the course of their training should be trained on how to design, develop and use multimedia instructional packages to foster learning and also, in-service teachers should be trained on how to develop and integrate multimedia instructional packages in their classes.

iv. School administrators should be oriented on the benefits of using multimedia packages in teaching their students.

\section{References}

Agboghoroma, T. E. \& Oyovwi, E. O. (2015). Evaluating Effect of Students Academic Achievement on Identified Difficult Concepts in Senior Secondary School Biology in Delta State. Journal of Education and Practice, 6(30), ISSN 2222-1735 (paper) ISSN 2222-288X (Online)

Ahmed, M. A., \& Abimbola, I. O. (2011). Influence of teaching experience and school location on Biology teachers' rating of the difficult levels of nutrition concepts in Ilorin, Nigeria. JOSTMED, 7(2), 52-61.

Ayittey, A., Arthur-Nyarko, E., \& Onuman, F. (2019). Impact of Multimedia Instruction in Biology on Senior High School Students' Achievement. Computer Science and Information Technology 7(5), 162-173. https://doi.org/10.13189/csit.2019.070502.

Bawden (1990). User-oriented evaluation of information services. Aldershot, England: Gower.

Beydogan, H. Ö. \& Hayran, Z. (2015). The effect of multimedia-based learning on the concept of learning levels and attitudes of students. Eurasian Journal of Educational Research, 60, 261-280. https://doi.org/10.14689/ejer.2015.60.14

Carmichael, M., Reid, A-K., \& Karpicke, J. D. (2018). Assessing the Impact of Educational Video on Student Engagement, Critical Thinking and Learning: The Current State of Play. A SAGE Whitepaper, SAGE Publishing, 1-21.

Chakraborty, M. (2019). Impact of Mulitimedia on Learners Enggement: An Experimntal Study. Journal of Information and Computational Science, 9(10), 196-206, ISSN: 1548-7741.

Cimer, A. (2012). What makes biology learning difficult and effective: students' views. Educational research and reviews,7(3), $61-71$.

Dabholkar, P. \& Bagozzi, R. (2002). An attitudinal model of technology-based self-service: moderating effects of customer traits and situational factors. Journal of the academy of marketing science - J ACAD MARK SCI. 30, 184-201. https://doi.org/10.1177/0092070302303001

Davis, F. (1989). Perceived usefulness, perceived ease of use, and user acceptance of information technology. MIS Quarterly, 13(3), 319 - 340.

Davis, F. D., Bagozzi, R. P. \& Warshaw, P. R. (1989). User acceptance of computer technology: A comparison of two theoretical models. Management Science, 35(8), 982-1002.

Davies, R. S., \& West, R. E. (2014). Technology integration in schools. In Handbook of research on educational communications and technology (4th ed., pp. 841-853). Springer New York.

Dagnew, A. (2017). The Relationship Between Students Attitudes Towards Schools, Values of Education, Achievement Motivation and Academic Achievement in Gondar Secondary Schools, Ethiopia. Research in Pedagogy, 3(1), 30-42. https://doi.org/10.17810/2015.46

Ercan, O. (2014). The Effects of Multimedia Learning Material on Students' Academic Achievement and Attitude towards Science Courses. Journal of Baltic Science Education, 13(5), 608-621, ISSN 16483898.

Etobro, B.A., \& Fabinu, E. O. (2017). Students' Perceptions of Difficult Concepts in Biology in Senior Secondary Schools in Lagos State. Global Journal of Educational Research, 16, 139-147, ISSN 15966224. http://dx.doi.org/10.4314/gjedr.v16i2.8.

Fisbien, M., \& Ajzen, I. (1975). Belief, Attitude, Intention and Behaviour: an introduction to theory and research. Reading, MA: Addison Wesley

Gambari, A. I., Shittu, A. T., Daramola, F. O., \& James, M. (2016). Effects of Video-Based Cooperative, Competitive and Individualized Instructional Strategies on the Performance of Senior Secondary Schools Students in Geometry. Malaysian Online Journal of Educational Sciences, 4(4).

Gambari, I.A., Yaki, A. A., Gana, E. S., \& Ughovwa, Q. E. (2014), Improving Secondary School Students' Achievement and Retention in Biology through Video-based Multimedia Instruction. Insight: Journal of Scholarly Teaching, 9, $78-91$. 
Gimba, R. W., Hassan, A. M., Yaki, A. A., \& Chado, A. M. (2018). Teachers' and Students' Perceptions on the Problems of Effective Teaching and Learning of Science and Technology in Junior Secondary Schools. Malaysian Online Journal of Educational Sciences 6(1), 34-42.

Gros, B., Garcia, 1., \& Escofet, A. (2012). Beyond the Net Generation Debate: A Comparison between Digital Learners in Face-to-Face and Virtual Universities. The International Review of Research in Open and Distributed Learning, 13(4), 190-210, https://doi.org/10.19173/irrodl.v13i4.1305

Hussein, Z. (2016). Leading to intention: the role of attitude in relation to technology acceptance model in ELearning. IEEE International Symposium on Robotics and Intelligent Sensors, IRIS 2016, 17-20, Tokyo,

Japan. Procedia Computer Science 105(2017): 159-164. Https://doi.org/10.1016/j.procs.2017.01.196

Ilhan, G. O., \& Oruç, S. (2016). Effect of the use of multimedia on students' performance: A case study of social studies class. Educational Research and Reviews, 11(8), pp. 877-882, Article Number: 5047F0A58349. ISSN 1990-3839. https://doi.org/10.5897/ERR2016.274

Janssen, S., \& O'Brien, M. (2014) Disentangling the Effects of Student Attitudes and Behaviors on Academic Performance. International Journal for the Scholarship of Teaching and Learning, 8(2). https://doi.org/10.20429/ijsotl.2014.080207

Jekinson, J. (2009). Measuring the effectiveness of Educational Technology: what are we Attempting to Measure? Electronic Journal of e-Learning, 7(3), 273-280.

Kareem, A. A. (2018). The use of Multimedia in Teaching Biology and its Impact on Students' learning outcomes. Conference Papers. University of Lagos Library and Information Service. Https://ir.unilag.edu.ng:8080/handle/123456789/3411.

Koseoglu, P., \& Efendioglu, A. (2015). Can a Multimedia Tool Help Students' Learning Performance in Complex Biology Subjects? South African Journal of Education, 35(4), 1-12, https://doi.org/10.15700/saje.v35n4a1169.

Loyd, B., \& Gressard, C. (1984a). The effects of sex, age, and computer experience on computer attitudes. AEDS Journal 18(2), 67-77.

Loyd, B. \& Gressard, C. (1984b). Reliability and factor validity of computer attitude scales. Educational and Psychological Measurement, 44(2), 501-505.

Legris, P., Ingham, J., \& Collerette, P. (2003). Why do People Use Information Technology? A Critical Review of the Technology Acceptance Model. Information and Management, 40, $191-204$.

Lipnevich A.A., Gjicali K., \& Krumm S. (2016). Understanding Attitudes in Education. In: Khine M.S., Areepattamannil S. (eds), Non-cognitive Skills and Factors in Educational Attainment. Contemporary Approaches to Research in Learning Innovations. Sense Publishers, Rotterdam, Online ISBN 978946300-591-3. https://doi.org/10.1007/978-94-6300-591-3_6

Mayer, R. E. (2003). Elements of a science of e-learning. Journal of Educational Computing Research, 29(3), 297-313.

Mayer, R. E. (2005). Cognitive theory of multimedia learning. In R.E. Mayer (Ed.), The Cambridge Handbook of Multimedia Learning. New York: Cambridge University Press.

Moreno, R., \& Mayer, R. E. (2000). A coherence effect in multimedia learning: The case for minimizing irrelevant sounds in the design of multimedia instructional messages. Journal of Educational Psychology, 92, 117-125.

Olaleye, F., Ajayi, A., \& Oyebola, B. (2017). Impact of Overcrowded Classroom on Academic Performance of Students in Selected Public Secondary Schools in Surelere Local Government of Lagos State. 110-132.

Omwirhiren, E. M., \& Anderso F. E. (2016). Effect of Class Size and Students' Attitude on Academic Performance in Chemistry at Demonstration Secondary School, IOSR Journal of Research \& Method in Education (IOSR-JRME) e-ISSN: 2320-7388, p-ISSN: 2320- 737X, 6(1), 01-06.

Sahronih, S., Purwanto, A., \& Sumantri, M. S. (2019). The Effect of Interactive Learning Media on Students' Science Learning Outcomes. ICIET 2019: Proceedings of the 2019 7th International Conference on Information and Education Technology March 2019, 20-24. https://doi.org/10.1145/3323771.3323797

Shah, I., \& Khan, M. (2015). Impact of Multimedia-aided Teaching on Students' Academic Achievement and Attitude at Elementary Level Iqbal. US-China Education Review A, 5(5), 349-360. https://doi.org/10.17265/2161-623X/2015.05.006

Smith, Ru., Cavanaugh, C., \& Moore, W. (2011). Instructional multimedia: An investigation of student and instructor attitudes and student study behavior. BMC medical education. 11.38. Https://doi.org/10.1186/1472-6920-11-38.

Smith, P.L., \& Ragan, T.J. (1999). Instructional Design. New York: Macmillan Publishing Company

Sölpük, N. (2017). The Effect of Attitude on Student Achievement. In: Karadag E. (eds) The Factors Affecting Student Achievement. Springer, Cham. https://doi.org/10.1007/978-3-319-56083-0_4. Print ISBN 9783319-56082-3 Online ISBN 978-3-319-56083-0

Stillman, J. (2018). New Stanford Study: A Positive Attitude Literally Makes Your Brain Work Better. 
https://www.inc.com/jessica-stillman/stanford-research-attitude-matters-as-much-as-iq-inkidssuccess.html (Accessed on 19/6/2020).

Sweller, J. (1994). Cognitive load theory, learning difficulty, and instructional design. Learning and Instruction, 4, 295-312.

Teo, T., Zhou, M., Fan, A.C.W. (2019) Factors that influence university students' intention to use Moodle: a study in Macau. Education Tech Research Dev 67, 749-766. https://doi.org/10.1007/s11423-01909650-x

Topală, I. (2014). Attitudes towards Academic Learning and Learning Satisfaction in Adult Students. Procedia - Social and Behavioral Sciences, 142(2014), 227-234. Https://doi.org/10.1016/j.sbspro.2014.07.583.

Vagg, T., Balta, J., Bolger, A., \& Lone, M. (2020). Multimedia in Education: What do the Students Think? Health Professions Education. Https://doi.org/10.1016/j.hpe.2020.04.011.

Verešová, M., \& Mala, D. (2016). Attitude towards School and Learning and Academic Achievement of Adolescents. The European Proceedings of Social and Behavioural Sciences EpSBS, http://dx.doi.org/10.15405/epsbs.2016.11.90. eISSN: 2357-1330, 870-876.

Vilia, P. N., Candeias, A. A., Neto, A. S., Franco, M. S., \& Melo, M. (2017). Academic Achievement in Physics-Chemistry: The Predicting Effect of Attitudes and Reasoning Abilities. Frontiers in Psychology, 28, 1-9. https://doi.org/10.3389/fpsyg.2017.01064.

Weng, F., Yang, R-J., Ho, H-J., \& Su, H-M., (2018). A TAM - Based study of the Attitude towards Use Intention of Multimedia among School Teachers. Applied System Innovation. 1(36), 1-9, https://doi.org/10.3390/asi1030036

Weng, F., Ho, H., Yang, R., \& Weng, C. (2019). The Influence of Learning Style on Learning Attitude with Multimedia Teaching Materials. Eurasia Journal of Mathematics, Science and Technology Education, 15(1), em1659. https://doi.org/10.29333/ejmste/100389

Yeşilbağ, S., Korkmaz, Ö. \& Çakir, R. (2020). The effect of educational computer games on students' academic achievements and attitudes towards English lesson. Educ Inf Technol (2020). https://doi.org/10.1007/s10639-020-10216-1

Záhorec, J., Haškova, A., \& Bílek, M. (2014). Impact of Multimedia Assisted Teaching on Student Attitudes to Science Subjects. Journal of Baltic Science Education, 13(3), 361-380. ISSN 1648-3898. 


\section{Appendix 1. Multimedia Instructional Package Attitudinal Scale for Biology Students}

\section{Dear student,}

This questionnaire is specifically designed for the purpose of evaluating the acceptability, usability and effectiveness of the multimedia instructional package you interacted with earlier. Responses are strictly for educational purpose.

Kindly fill or tick as appropriate. Thanks for your cooperation.

\section{Section A: Personal Data}

Kindly fill in and tick in the blank spaces provided below:

1. Name of School

2. Sex Male Female

\section{Section B: Kindly tick as appropriate [ ]}

SA Strongly Agree

SD Strongly Disagree

U uncertain A Agree

D Disagree

\begin{tabular}{|l|l|l|l|l|l|}
\hline & ATTITUE & SA & A & U & D \\
\hline 1. & I feel very confident in using the multimedia instructional package & & & & \\
\hline 2. & The Multimedia package allows me to learn on my own & & & & \\
\hline 3. & Using the multimedia presentation for learning is a good idea & & & \\
\hline 4. & I find the multimedia package very interesting for learning & & & \\
\hline 5. & I enjoyed the evaluation questions in the package & & & & \\
\hline 6. & $\begin{array}{l}\text { I know I will perform better in Biology if my teacher frequently uses } \\
\text { multimedia packages like this to teach other topics }\end{array}$ & & & & \\
\hline 7. & I like the navigational structure of the package & & & & \\
\hline 8. & The package gives me confidence in interacting with the computer & & & & \\
\hline 9. & The package does not satisfy my need for instructions. & & & & \\
\hline 10. & The time I spent using the package is a waste & & & \\
\hline
\end{tabular}




\section{Appendix 2. The Biology Achievement Test (BAT)}

\section{Section A: Kindly fill and tick in the blank spaces provided below:}

3. Name of School

4. Name of Student

5. Sex: Male Female

6. Age:

\section{Section B:}

Answer the following questions by circling the correct answer or supplying the correct answer. You have 25 minutes (good luck).

1. Which of the following statement is true about the structure of a chromosome?

A chromosome consists of :

a. Two chromatids joined at the centromere b. two chromatids joined at the spindle c. two chromatid threads joined at the spindle d. thread-like structure not joined together

2. Chromosome pairs $1-22$ are called
a. centromere b. autosomes
c. sex chromosomes
d. linkage 3 . What is the

ploidy number of dog?
a. 46
b. 48 c. 78
d. 76

4. Two sister chromatids are held together by

a. centromere b. centrosome c. DNA d. spindle fibre

5. The chromosome contains the following EXCEPT

a. lysosome b. DNA c. genes d. centromere

6. The haploid number of chromosomes in humans are
$\begin{array}{llll}\text { a. } 46 & \text { b. } 72 & \text { c. } 42 & \text { d. } 24\end{array}$

7. Which of the following statements is correct about the chromosomes in the gamete? At the end of the second meiotic division,

a. each gamete contains only paternal hereditary information b. chromosomes in the four gamete cells are diploid in number c. chromosomes contains only a random mixture of paternal and maternal chromosomes d. chromosomes contains only maternal hereditary information

8. Before a cell divides, all the following will happen EXCEPT

a. DNA duplication b. cell elongation c. cell shrinks d. proteins are synthesized or produced

9. How many chromosomes are found in the human female gonad?
a. 46 b. 23 c. 33 d. 13

10. In the cell cycle, the first gap of growth is called

$\begin{array}{llll}\text { a. G1 b. G0 } & \text { c. M2 } & \text { d. S-phase }\end{array}$

11. The process by which the cytoplasm separates is called
a. plasmolysis b. mitosis
c. cytokinesis
d. meiosis

12. Cytokinesis of mitosis is a process that ensures that

a. each daughter cell gets the necessary organelle b. there is distribution of a complete set of genes in each daughter cell c. daughter cells inherit new genetic combination d. worn out organelles are excluded from daughter cells

13. Which of the following best describes homologous chromosomes? they are:

a. a product of the division of a chromosome b. two identical chromosomes from each parents c. chromosomes arranged in spindle fibres during cell division d. daughter cells formed during meiotic division

14.

$\begin{array}{llll}\text { a. growth of organisms } & \text { b. regeneration of bogy parts } & \text { c. production of gametes } & d \text {. increase in organism }\end{array}$ size

15. Which of the following occurrence is not a feature of meiosis?
a. formation of four haploid daughter cells
b. two successive nuclear division
c. pairing of homologous chromosomes at prophase $d$. formation of two diploid cells

16. is the function or role of meiosis
$\begin{array}{lll}\text { a. growth of organisms } & \text { b. regeneration of body parts }\end{array}$
c. production of gametes d. making clones

17. takes place in sex cells or gonads

a. mitosis b. meiosis

18. Which of the following stages occurs before mitosis begins

a. prophase b. metaphase c. interphase d. telophase 
19. During which stage does the g1, s and g2 phases occur

a. interphase b. metaphase c. telophase d. cytokinesis

20. The mitotic phase in which chromosomes align or arrange themselves in the center of the cell is called

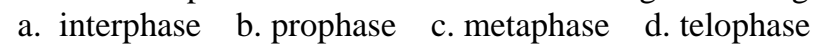

21. At which of the following stages of mitosis do the two daughter chromosomes separate completely?

a. prophase b. metaphase c. anaphase d. telophase

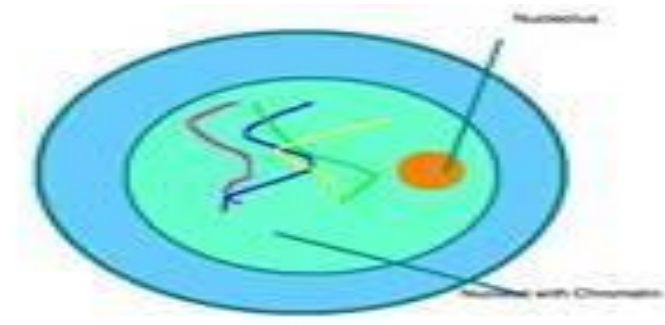

Use the diagram below to answer questions 22 and 23

22. The diagram represents which phase during cell division

a. prophase b. interphase c. telophase d. metaphase

23. The part labeled 1 is the -
a. nucleus
b. cytoplasm
c. chromosome d. cell membrane

24. Which of the following is found in meiosis but not in mitosis
a. chromatids
b. prophase
c. crossing over d. spindle fibres

25. Two chromosomes or four chromatids are called
a. diploid
b. haploid c. tetrad
d. homologous chromosomes

26. The site in which crossing over happens during meiotic division is called
a. chiasmata
b. synapsis
c. chromatid d. homologue

27. Crossing over occurs during which meiotic phase
a. metaphase I
b. prophase I c.
c. anaphase I
d. metaphase II

28. At what stage in meiosis does the cytoplasm break to give four daughter cells
a.anaphase II
b. telophase II
c. metaphase II
d. prophase II

29. A cell containing 20 diploid chromosomes at the beginning of meiosis would, at its completion, produce cells containing how many chromosomes?

a. 5 b. 40 c. 10 d. 2

30. Which of the following causes variation in individuals such that offsprings don't look alike?
a. meiosis b. mitosis
c. telophase
d. cytokinesis 


\section{Appendix 3. Focus Group Discussion Guide}

1. Did you find the package easy to use?
a. Navigation
b. Graphics

2. Do you think the package would aid your learning? Give the reason(s) for your answer

3. How often do you intend using the package?

4. Do you think the package would aid your performance in Biology?

5. What do you like about the package?

6. What do you dislike about the package?

7. Would you like to share the package with others who do not have it? 